\title{
Working days in a London construction team in the eighteenth century: evidence from St Paul's Cathedral
}

Judy Z Stephenson

University College London

Bartlett School

Accepted at The Economic History Review April 2019

\begin{abstract}
:
This article provides new information and data on the work and pay of skilled and semi-skilled men on a large London construction project in the early 1700 s. It offers firm-level evidence on the employment relation in the construction industry at the time and sheds some light on the number of days worked per year and per week, showing that employment was more irregular and seasonal than current estimates of income infer. The patterns are considered in the context of new debates about industriousness and economic growth.
\end{abstract}

\section{I}

Building craftsmen have been the universal stand in for the 'average' urban skilled worker in real wage series and macroeconomic analysis for over a century, however economic historians have virtually no evidence-based wage or working hours material with which to understand the relationship between their working time and income. Real wage estimates for them have always assumed a number of days worked, or used other sources - prices; consumption; depositions; to estimate the number. The most recent of these asserts that early modern workers toiled for over 250 days a year by the first decade of the eighteenth century. This paper uses significant new primary source material to take a different approach to days worked, by analysing actual working team records on an important construction project in the first decade of the eighteenth century. It highlights that working patterns in the construction industry have always been, and remain, seasonal and stage dependant, limiting the number of days that could be worked by most people. The patterns found have implications for our understanding of how wages formed income and how higher work intensities, or industriousness can have contributed to income and growth.

The length of the working year in England is at the core of the two most important narratives about pre-industrial development; living standards or income, and productivity or labour 'industriousness'. In terms of living standards, the vast majority of the literature has viewed economic growth and real wage growth as correlated to the extent of treating the real wage as 
a proxy for economic growth. ${ }^{1}$ Until now, that real wage has been calculated by multiplying 'day wages' from building contractor's bills by an assumed or estimated number of days worked per year to determine annual income. ${ }^{2}$ This is compared to the price of a basket of consumption goods in order to derive a real wage. Since the inception of such calculations in the 1930s they have thrown up a paradox of declining real incomes during eighteenth century industrialization. ${ }^{3}$ A large and influential literature has explored this paradox and suggested that real wages rose or held steady because workers worked more days in the year than before, a phenomenon described as the 'industrious revolution'. Originally this increased work intensity was tied up with late eighteenth century development as the working classes were forced into harder labour by capitalism and factory discipline. ${ }^{4}$ Since the early 1990s Jan deVries' 'industriousness' has had a more positive spin, where workers (men and women) gave up leisure and homemaking days and hours to supply labour to the 'market 'thereby bringing about economic growth. ${ }^{5}$

More recently, this industrious revolution has been dated to the seventeenth century and earlier. ${ }^{6}$ Broadberry et al highlight that estimates for agricultural workers' working days before 1550 are above 250 per annum, (although it is thought that London workers, due to their higher wages may have only worked over 250 days after 1760). ${ }^{7}$ Such figures highlight the relative lack of research on unemployment, underemployment and leisure in the early modern period, although in the mid twentieth century the consensus was that all three were prevalent. $^{8}$

\footnotetext{
${ }^{1}$ This tradition is the key assumption in recent work but see the summary of the relationship between them in Humphries and Weisdorf 'Unreal wages' p.2; Angeles 'GDP per capita and real wages', pp.147-156 and table 3, and a full discussion in Broadberry et al, 'British Economic Growth', pp. 247-278.

${ }^{2}$ For this period a craftsman is assumed to have had 250 days work at 30d. giving an income of $£ 31.25$ and a labourer 250 days at $22-24 \mathrm{~d}$ giving an income of $£ 22.91-£ 25.00$. For discussion of the rates see Boulton 'Wage Labour', Schwarz 'Standard of Living', and Allen 'Prices and Wages'.

${ }^{3}$ There are varying estimates for real wages, this is best illustrated for London in Schwarz, 'Standard of Living', figure 1, also see Allen's series at https://www.nuffield.ox.ac.uk/people/sites/allen-research-pages/; Phelps Brown Hopkins, 'Seven centuries', Voth 'The longest years' p.1080, although see Clark 'The condition of the working class' figures 4 and 5 (pp. 1311-1312) for a more positive view for the whole of the UK. The variations in different real wage estimates are derived from different price series - they all use the same nominal wage data. ${ }^{4}$ E. P. Thompson, 'Time, Work-Discipline, and Industrial Capitalism', pp.56-97. Also see Clark, 'Factory discipline'. An excellent critique of the assumptions that underpin Thompson is in Glennie and Thrift 'Reworking E.P. Thompsons Time and Work Discipline'.

${ }^{5}$ Jan De Vries, The Industrious Revolution

${ }^{6}$ Humphries and Weisdorf, 'Unreal wages'.

${ }^{7}$ Broadberry et al, British Economic Growth, p.264; Allen and Weisdorf 'Was there an industrious Revolution?'

${ }^{8}$ Coleman, 'Labour in the English Economy of the Seventeenth Century', pp.288-89, Thomas, 'Work \& Leisure'.
} 
The declining real wage paradox is complicated by the fact that whilst wage series assume that the income they depict is representative of the average worker, there has been a lack of substantive examples of working practice or data from the construction industry where the 'average' wages have traditionally been collected from. The exception is Donald Woodward's study of building craftsmen and labourers in the northern towns. Woodward found more seasonality and variation than is usually considered, with a lower number average number of days worked per year than found in other usually cited sources. He presented cases from the 1690s where regularly employed men worked fewer than 200 days per year, with the firm implication that more casually employed men would have had even less. ${ }^{9}$

The latest estimates of annual days worked for all of England from Humphries and Weisdorf (based on the number of days in casual work needed to earn an annual worker's yearly income including the non-pecuniary benefits) show a clear, dramatically increasing, trend in the number of days worked per year over the latter part of the seventeenth century, with an average of just over 200 days worked in 1650 rising to in excess of 250 days by 1700 and more than 300 after $1750 .{ }^{10}$ If this is the case then, even accounting for differences in day pay current estimates for London workers welfare throughout the late seventeenth century and eighteenth may not be correct. ${ }^{11}$

The implication of 'industriousness' theories is that labour made the decision to participate more fully in the market or supply more labour. ${ }^{12}$ The mechanisms by which this earlier more industrious working year came about are, as Humphries and Weisdorf point out, unknown. ${ }^{13}$ Before deVries's industrious thesis the fact that early modern work was irregular, nonroutinised, and did not follow patterns of what modernity understands to be the working week was well established. ${ }^{14}$ However, significant attempts to prove that industriousness increased

\footnotetext{
${ }^{9}$ Woodward Men at Work, pp. 127. Although Woodward's day rates are used by Allen 'Great Divergence' his working days data were not.

${ }^{10}$ Humphries and Weisdorf 'Unreal Wages', figure 8.

${ }^{11}$ Stephenson, 'Real' Wages? shows the wages paid to men were lower by $20-30 \%$, if the number of days were higher as asserted by Humphries and Weisdorf then welfare effects might be mitigated.

${ }^{12}$ DeVries, Industrious Revolution, p.210-214. See Clark 'Factory Discipline' for an unconventional discussion of this that predates the industriousness debate.

${ }^{13}$ Humphries and Weisdorf, Unreal wages, Economic Journal, Forthcoming. p.30

${ }^{14}$ Important earlier contribution of historians to analysis of working patterns through the analysis of leisure time and marriage occasion tend not to be discussed currently, see Reid, 'Saint Monday Revisited', Boulton

'Economy of Time? Wedding days and the working week in the past' p.38
} 
in the eighteenth century, have not used working records. ${ }^{15}$ The current predominant method of estimating working days uses a basket of basic consumption goods, and an average daily wage (or day rate) to calculate the working year required to achieve it. ${ }^{16}$ This method, first advanced by Allen and Weisdorf, broke with the convention that the number of days worked per year was fixed, and instead assumed that welfare was stable and the workers moderated their days spent working to achieve a standard of living. It showed the gap between the estimated number of days worked per year and the number of days work needed to buy the consumption basket in Allen (2001) grew, and interpreted this gap as industriousness, implying that workers put in more days of labour than required for basic subsistence. By using the basket of goods to determine days worked Allen and Weisdorf and Humphries and Weisdorf imply that necessity or aspiration for consumption were the drivers for increasing industriousness. ${ }^{17}$ The important and completely unanswered question is, of course, whether a concomitant demand for labour made extra work easy to come by for those who wanted or needed to work more. ${ }^{18}$

Implicit but core to all real wage scholarship to date, particularly for the period before 1850 , is that builder's or others day wages, not just the annual income they would have attained, are representative of average daily income from any other occupation. ${ }^{19}$ In truth, there are two potential problems with this assumption. Most early modern urban workers were not in receipt of day wages but were paid by the piece (mostly for manufacturing), received commission and fees, or were retained for services. Records will never give us an indication of how many hours they put in, nor effort. Secondly there is precious little evidence of the number of days that builders did actually work. Nevertheless, the builder's income stands as proxy for the average.

\footnotetext{
${ }^{15}$ Voth, 'Time and Work in Eighteenth-Century London', pp. 29-58. See Figure 2, p.719; Voth 'The Longest Years' Table 3, p.1071 used court depositions of eighteenth-century Londoners regarding the hours at which they went to and left work.

${ }^{16}$ Allen and Weisdorf, 'Was There an Industrious Revolution before the Industrial Revolution? pp. 715-29, The method is continued in Humphries and Weisdorf 'Unreal wages'. '

${ }^{17}$ Ibid., figure 1, figure 2. p.719; Allen, 'Prices and Wages in Southern England'; Allen, 'The Great Divergence', Table 1; there is considerable scope for work on seventeeth century leisure and education and their effects on work time. See Harris 'Bawdy house riots', Marfany 'Early modern Leisure'

${ }^{18}$ De Vries, The Industrious Revolution, p.200-250. Note also a literature that suggests lack of nutrition limited the number of days effort that could be sustained, where food had given earlier work "a pattern in which intense, seasonal activity with long hours of work alternat[ed] with extensive periods of rest and recuperation.", Voth 'Working hours during the industrial revolution' p.5, Freudenberger \& Cummins 'Health, Work, and Leisure' p.9, Voth subsequently moved away from the nutrition thesis 'The Longest Years'.

${ }^{19}$ The practice of this assumption originates with Phelps Brown Hopkins 'Seven Centuries'. See Feinstein, Pessimism Perpetuated, pp.627, 633, 647, 649 for a well annotated consideration of the time wage relationship when being dealt with in a quantitative approach.
} 
Attempts to calculate the working year in hours complicates matters because there is not enough information from eighteenth century sources to be sure of them. ${ }^{20}$ Voth's evidence, sourced from London is not robust enough to say with certainty that employing organizations extended work hours, and that evidence has never been offered, and in fact, the existing literature on construction hours has tended towards the view that hours of work decreased over time. ${ }^{21}$ Certainly, they did in the nineteenth century as builders agitated for an eight or nine-hour day from the $1830 \mathrm{~s} .{ }^{22}$ Woodward found most construction work in northern towns before 1750 was carried out between 6 a.m. and 6 p.m., although there are some instances of twelve or thirteen hours worked, but also, potentially shorter hours in winter. ${ }^{23}$ Days, tides and other timed units of pay are rarely directly measured in hours in any records, so it is entirely possible that men worked variable hours for the same pay. ${ }^{24}$ Construction workers in London and other large towns were not paid hourly rates until 1860, and the introduction of hourly pay was associated with increased hardship. ${ }^{25}$ Of course, if hours were extended in construction during the eighteenth century then many workers were being paid less per hour in 1775 than they were in 1700 , because nominal day rates, like those of the contractor's bills, were extraordinarily rigid. ${ }^{26}$

This paper offers new evidence from an important early eighteenth-century construction site St Paul's Cathedral - which was the biggest and most important site in the City of London or Westminster in the decades after the Great Fire. It uses the working records of a prominent mason contractor of the actual number of days men in his team worked throughout the busy decade 1700-1709 as the West Front and Dome were completed. The evidence is somewhat at odds with the recent industriousness research, and suggests that the number of days worked per annum by urban construction workers was lower than current estimates. Construction work was affected by frictions that workers faced in searching for work and in moving

\footnotetext{
${ }^{20}$ Voth, 'Time and Work', pp.30,35-36, 46

${ }^{21}$ See Gilboy, Wages in England, p.8

${ }^{22}$ Postgate, pp.97, 135-6.

${ }^{23}$ Woodward, Men at work, pp.122-127.

${ }^{24}$ That time became a measure of productivity only in the mid nineteenth century is the essence of the Hobsbawm thesis of 'Custom, Wages and workload'.

${ }^{25}$ Postgate, Builders History, pp.209-210

${ }^{26}$ Feinstein concluded the hours held stable, 'Pessimism perpetuated'p.649, - and it is useful to do the same here. For instance, the day rate for the directly paid labourers at St Paul's did not increase between 1675 and 1748 .
} 
between employers. ${ }^{27}$ The new data is limited by the fact that it comes from one urban source only, (and cannot be extended to analysis of agricultural workers, or those on annual contracts)|. ${ }^{28}$ Nevertheless, the patterns found are sufficiently related to the historiography of urban work to stimulate further debate and research on the mechanisms through which working patterns became more regular, and more frequent. Moreover, they show that builder's wages vary in amount per day and in number of days worked, therefore one rate at 250 days is a poor proxy for the reality of how much labour worked.

\section{II}

Building sites, and building workers are potentially problematic as representative cases for studying working hours. As building is capital intensive, and external conditions such as finance, weather, the cost of alternative accommodation etc. all accumulate costs throughout the building period, most building sites aim for intensive work. However, building labour demand is stage dependent. Bricklayers only lay after foundations have been dug. Joiners only fit architrave to existing doorways. Plumbers cannot fit gutters until there are walls and roofs to fit them to. Building work is also generally thought to be seasonal. Subcontracting and self-employment are the predominant organizational forms. As a result, although building accounts will record a high number of hours operational, and a large number of men on site, (as Voth used the example of the Burnton \& Western canal building in 1801 to illustrate a more industrious working year), skilled workers are only likely to have a full year's work in any specific skill if they work for a large firm that plans the logistics of ongoing consecutive jobs, or in other skills if they are willing to be a jack-of-all-trades. ${ }^{29}$

Although these stage dependant and seasonal factors are a feature of construction everywhere London construction in the seventeenth and eighteenth centuries seems to have been organised to allow a high work intensity. Generally, all available building records show that sites in London were operational six days a week, fifty-two weeks a year throughout the period. ${ }^{30}$ There is no evidence of formal holy-days or Saint days other than Christmas and

\footnotetext{
${ }^{27}$ The concept of search for work is explained in economic terms in Burdett 'Theory of Employee Job Search and Quit Rates'

${ }^{28}$ For recent work on seasonality in agriculture see Burnette 'The seasonality of agricultural employment: Evidence from Farm accounts 1780 - 1840', and 'Seasonal Patterns of Agricultural Day-Labour at Eight English Farms, 1835-1844'

${ }^{29}$ Voth acknowledged seasonality, although he didn't have individual observations so could only surmise from aggregated working records. Voth, 'Time and work in Eighteenth Century England' pp. 47-49

${ }^{30}$ See TNA Work 5/1-74, LMA CLA/ 004/7/
} 
Easter which precluded work in any institutional accounts. Sites were open to allow access for as many trades as possible to work without getting in each other's way. Supply chains and ancillary and professional services, such as transport, surveyors, solicitors, administrators and financial staff were all closely interlinked with the construction industry. In such an environment if men wanted to work as many days as possible there were no formal constraints to stop them.

The data described in this paper comes from an exceptionally skilled labour force, masons at St Paul's Cathedral 1700-1709, recorded in two daybooks of William Kempster, who was mason contractor at St Paul's Cathedral 1700 - 1717. They are in all just under 300 pages, most of which contain weekly records of men's names, the number of days they had worked that week, and the pay given to them for that week. (See Image 1, and Image 2.) ${ }^{31}$ The first book gives weekly records of men's work and pay from 12 October 1700 to the same week 1702. The second book commences in March 1706 and covers the period until June 1709. Records are clearly marked St Paul's Cathedral, and tally with the Cathedral's records of Kempster's bills. ${ }^{32}$ Kempster was working at St Paul's until 1717, so, it is probable that there were other books, now missing. ${ }^{33}$ Although this wage evidence is fragmentary, and can offer very little insight into the labour market or labour force in London at the time it is the only of its kind currently available, and gives us the real working patterns and pay records for 179 men of skill and experience working on the most important site of the period over a decade. Many of the team worked not only for Kempster but others in the same period. ${ }^{34}$ (Table 1 and 2. $)^{35}$

Table 1. No. of men on site in Kempster team 1700-9: total no. of men observed in 52-week period

$$
1700-1
$$
$1701-2$ $1706-7$ $1707-8$ $1708-9$

\footnotetext{
31 The books are at The National Archives, C106/145.

${ }^{32}$ See the Cathedral's accounts at CLC 313/I/B/25473 no's 34 - 46. The Wren Society transcribed many of these, Vols. XIII, XV.

${ }^{33}$ Major construction was completed by 1711 however.

${ }^{34}$ The period under review was one of renewed warfare for Englishmen on European battlefields. All the evidence is that the very unskilled were called up involuntarily, and indeed there is no reference in St Paul's minutes to labour called up or impressed for the war. Kempster was also working at St Pauls' throughout 17035 , probably with some of the men listed in the earlier and later books, but the book(s) are not present.) Some of the men are readily identifiable from other St Paul's records or mason company searches. Others, in fact the vast majority, can't be traced elsewhere, and as table 2 shows, about two thirds of the sample only worked for Kempster for a short time, appearing in only one year's records

35 The source for all tables and figures is the author's input and analysis of TNA C106/145.
} 
$\begin{array}{llllll}\text { Total no. of } & 28 & 19 & 102 & 65 & 77\end{array}$

men

Table 2. No. of years men were present in the team

\begin{tabular}{lllll}
$<1$ year & $>1,<2$ years & $>2,<3$ years & $>3,<4$ years & $>4$ years \\
\hline 120 & 26 & 23 & none & 10
\end{tabular}

In all, it is possible to extract from the records five 52-week periods which form the basis for the figures calculated and presented in this paper; two consecutive years beginning in October 1700: and three consecutive years from March 1706 to March 1709. During this period, Kempster's team built the south west tower, erected the famous geometric staircase there, fitted the stonework of the library, and also set and carved the columns on the west front. Most of the carving work at St Paul's was done by masons, and Kempster's team will have included several.

There were, of course, men in the team who were responsible for managing others. Michael Growden, who worked for Kempster from 1706, (if not before) was recorded on the Cathedral's books as 'master' in masons lists in the years following this, and Joshua Fletcher, who was foreman and involved in controversy at the Cathedral in 1710 worked for Kempster for at least three years. There are two or more hands which have written in the books, as one might expect if a foreman or apprentice were assisting with record keeping. Generally, there is a double page assigned per week, with men's days struck off on one side, and payment made recorded on the other, but when short of space both records were squeezed into one page. In some places two weeks were listed top and bottom, and in a couple of instances four weeks of wage payments were recorded on a double page. There are corrections crossingsout, and a few mistakes. On a couple of occasions only the number of days worked was recorded, but no pay. On others the days struck off say that five days were worked but payment made for six, and on another the opposite. Sometimes individual men are clearly expected to have been working - their name appears in the middle of the list - but no days or pay were recorded for them. At others, a payment for a number of days appears on the bottom of a list with no prior records as a new man must have joined the team.

The maximum possible number of days paid for in any week was usually six. In some late December weeks men were paid for more than six days, but the books also indicate that those 
excess days may have been worked in the week after Christmas. In May 1706 one man, Joseph Smith, a very senior and experienced mason who had worked at St Paul's since the 1690s was paid for two weeks, but no explanation was given. These are all small occurrences however, and generally, the books are consistent, well organized, and well preserved considering the three centuries that have passed since they were used.

There are occasional small notes and memoranda which help in identifying men and work. On May $12^{\text {th }} 1708$, "I promise to pay into Mr Will Kempster the sum of five pounds upon demand witness my hand Tho Knagg”, which probably refers to the repayment of a loan. Knagg worked in every year of the records, and was one of the most hardworking men on site, so it might have been a safe bet to lend him money. On April $2^{\text {nd }} 1709$ it says "this week is all accounted in a March bill", and "Mr Richards 3 days this week putting up the steps in the staircases ... strings, Matt Wain and Nic Abraham 2 days each a fitting for him and labourers 6 days as on the church account. Masons more a peacing the columns; Peter Abraham Richard Day, Will Stonhouse, Mick Growden". This indicates that Richard Richards (who had worked previously for Kempster's father at St Paul's) may have been responsible for the staircase. His day rate was 30d. On June $4^{\text {th }} 1709$ "John Tuckey began to set the fli[ght] of steps at the west front May 26th 1709, ended the same August 24th 1709 it being Bartholomew's day". Tuckey was an experienced master mason, he earned 30d. per day putting him near the top of day rate pay. It is apparent that 30d. per day, which Allen, or Schwarz takes as the average skilled man's average day rate for that year was not an average day rate at all, but the rate that the most skilled master masons could command for innovative and important work. ${ }^{36}$ But, as we shall see the day rate that a man received was not a clear predictor of his income from the site.

It is not an entirely simple task to readily identify those who were craftsmen, and those who were labourers. However, in a small number of weeks in 1706 and 1708 Kempster recorded the pay of men under headings which indicate roles and skill. The classifications included "labourers", "masons on the call", "rough layers (and their labour)", and an unclassified list of

\footnotetext{
${ }^{36}$ This point, and the difference between the charge out rates found in the existing wage series, and the lower amounts men actually earned, are discussed in Stephenson, 'Real' Wages?'.
} 
workers. These, and the notes described above enable a general classification of the skill levels and pay ranges of those in the books as follows in Table $3 .{ }^{37}$

Table 3. Levels of skill and ranges of day rates paid in Kempster team

\begin{tabular}{lll} 
Skill level & Day rate range & No. in dataset \\
\hline Unskilled men & $10-17 \mathrm{~d}$. & 13 \\
Labourers & $18 \mathrm{~d}$. & 63 \\
Skilled fitters, layers, and & $19-27 \mathrm{~d}$. & 27 \\
hewers & & \\
Master masons & $28 \mathrm{~d}$. & 37 \\
Master masons and carvers & $30 \mathrm{~d}$. & 23 \\
Specialists & $32-34 \mathrm{~d}$. & 13 \\
Foremen and carvers & $36-40 \mathrm{~d}$. & 2 \\
Total & & 179
\end{tabular}

Note: Low-skilled men may have earned less than labourers because labourers commanded a premium over unskilled men for strength, or brawn (and trade-specific knowledge). See Stephenson, 'Pay of labourers'.

These day rate ranges were not entirely exclusive however. Some men worked at more than one rate. William Stonhouse, a citizen, free of the mason's company, who apprenticed one son to Kempster in 1710, and had his own apprentices, worked for both $28 \mathrm{~d}$. and day and $20 \mathrm{~d}$. a day. He had trained under the same master as Joshua Fletcher, one of the highest paid men. Both are known to have been at St Paul's in the 1690s. ${ }^{38}$ Fletcher, who was sufficiently important or known, as a foreman, to be in personal correspondence with the Commissioners for the rebuilding, was the son of a Westminster brewer and had been apprenticed in 1691 to Robert Bushnell (an established London mason's family). He became an established contractor in his own right. John Barker, the other most highly paid man, was trained by a carver and had been working with John Thompson, Kempster's predecessor at St Paul's in the 1690s. The 13 men paid over 30d. a day included John Magnus who had been an apprentice of Thompson's in 1681, and who had been working at St Paul's in the 1690s also. Many names of those listed at 30d. a day are known to have worked for other famous masons, Richard Richards for Christopher Kempster and Ephraim Beauchamp and Edward Strong; Will Ash and Joseph Smith for Edward Strong. Men listed at 28d. a day are mostly also found in apprenticeship and mason's company records, some with their own apprentices, and many of those working at 20,24, and 26d. a day have the family names of freemen masons. Two of

\footnotetext{
${ }^{37}$ Low skilled men may have earned less than labourers because labourers commanded a premium over unskilled men for strength, or brawn, (and trade specific knowledge), See Stephenson 'The pay of labourers'.

${ }^{38}$ Knoop and Jones, The London Mason pp. 66-78
} 
the 28d.-a-day men, Kempster's own son, and Richard Day were apprenticed to Kempster around 1700 and were bound to him during his contracts at St Paul's. In earlier parts of the book some days are recorded for them but no pay. From 1706 they were both paid 28d. per day each. ${ }^{39}$

At the lower end of the scale, at 18d. are mostly labourers, but also some masons. Will Showers is listed as a mason in a St Paul's account in 1704, but he worked for these years for Kempster at $18 \mathrm{~d}$. a day. ${ }^{40}$ Charles Thurland, also paid $18 \mathrm{~d}$. a day, who was related to Kempster, was listed as a labourer in the same account. It is possible that a significant number of the men at 18d. a day may have been masons rather than labourers. Sam Lightfood (Ledford) appears with Showers many times, and his father was apprenticed a mason, but there is no way to be certain of these skill levels. Whilst Kempster's team was working, the cathedral commissioners hired and paid directly large numbers of labourers to assist all trades and do general labouring across the site. They were paid, predominantly, 16d. a day in winter, and 18d. in summer. Their numbers were tallied by the cathedral's clerk of works but their work cannot be discerned from Kempster's books, so we cannot tell what interaction there was between the teams.

\section{III}

Table 4 (a. and b.) details the average number of days and weeks worked for all men, and at each pay rate for each of the 52-week periods. The annual averages are much lower than current estimates, but averages can be deceiving. The number of days or weeks worked per year by men varied a great deal. ${ }^{41}$ Five of Kempster's men (or 2.3\%) worked over 250 days per year consistently for him, and roughly fifteen per cent worked over 200 days in more than one year. But most men worked less than 150 days in a year for Kempster. If these averages were representative of working practice more generally then annual incomes would have been about half current estimates. ${ }^{42}$

Here we must continue in the tradition of some assumptions. Presumably, men worked elsewhere. In fact, we know that men moved between employers. Two of Kempster's men,

\footnotetext{
${ }^{39}$ Ibid. is the best source for masons' names and working practices on London sites in this period.

40 TNA C106/145; LMA CLC/B/I/313/003/25473, no 41.

${ }^{41}$ Allen 'Prices and Wages'; assumes that craftsmen or skilled workers in this period on average would have had 250 days work, (at 30d. a day, which would give an annual income of $£ 31.25$ )

${ }^{42}$ See note 2 above.
} 
Will Ash and Richard Richards, were recorded as working for Edward Strong in Greenwich in July 1700 before Kempster's day books begin. ${ }^{43}$ If a man worked a low number of days per week but was present on site the whole year it might be possible that Kempster was their only source of employment, but it is not plausible to say the same for someone who worked 150 days a year if he did so as a full six-day week for half the year, then disappeared from the records. There were many projects that stone masons or any building craftsmen could obtain work at near St Paul's in this period, but we don't have detailed building accounts for them. ${ }^{44}$ In order to understand these low average figures, we need to understand how much work there was available at St Paul's, and how it was distributed, and then develop assumptions about other employment.

Table 4a. Average annual days worked in Kempster team by day rate range

\begin{tabular}{ll} 
Day rate & Average no. of days worked p.a., 1700-9 \\
\hline$<18 d$. & 48.59 \\
18d. & 132.30 \\
19-27d. & 163.79 \\
28d. & 101.21 \\
29-30d. & 175.56 \\
32-34d. & 48.72 \\
36-40d. & 200.50
\end{tabular}

Table 4b. Average number of days worked for all men

\begin{tabular}{llllll} 
& $1700-1$ & $1701-2$ & $1706-7$ & $1707-8$ & $1708-9$ \\
\hline Average & 152.89 & 167.44 & 122.36 & 142.42 & 113.05 \\
Coefficient of & $62 \%$ & $55 \%$ & $73 \%$ & $68 \%$ & $88 \%$
\end{tabular}
variation

The Cathedral was open, and operative with men on site six days a week 52 weeks of the year. In all years in Kempster's books, (and other call books observed) there were only 4 days worked in the week with December $25^{\text {th }}$ in it, and two weeks usually after Lady Day which

\footnotetext{
${ }^{43}$ Recorded by Knoop and Jones, London Mason, p.89

44 The City churches were mostly completed by 1700, but a London building boom continued until after 1721 . See Guillery 'The Small House' pp. 25, 87-8, 154, 208
} 
had 5 working days in them. This was common practice on other sites too. This indicates a maximum working year of 308-9 days. The 53 saints or holy days that Voth supposed were lost throughout the early eighteenth century are not discernible in the St Paul's records. There was significant seasonal variation in the amount of work throughout the year though.

Generally, the seasonal pattern for Kempster was a high number of days worked in Michaelmas quarter, right up to Christmas, little work in January and February, a more fully operational team in March, and then a large number of men and amount of work from Lady Day to Michaelmas. Kempster's records show that his team was operative at St Paul's (his biggest contract, if not only one, at the time) for 47 weeks in 1700-1, 48 the following year, then in 1706-9 48, 49, and 48 weeks. The weeks that were not worked were mostly in January.

Figure 1. Average weekly total number of man days worked in any month $1700-1709$, expressed as a percentage of the highest month (July $=100 \%=182$ days) Note: The average weekly figure is arrived at by calculating total man days worked for all weeks, then taking a month average of this for all of the 5 years.

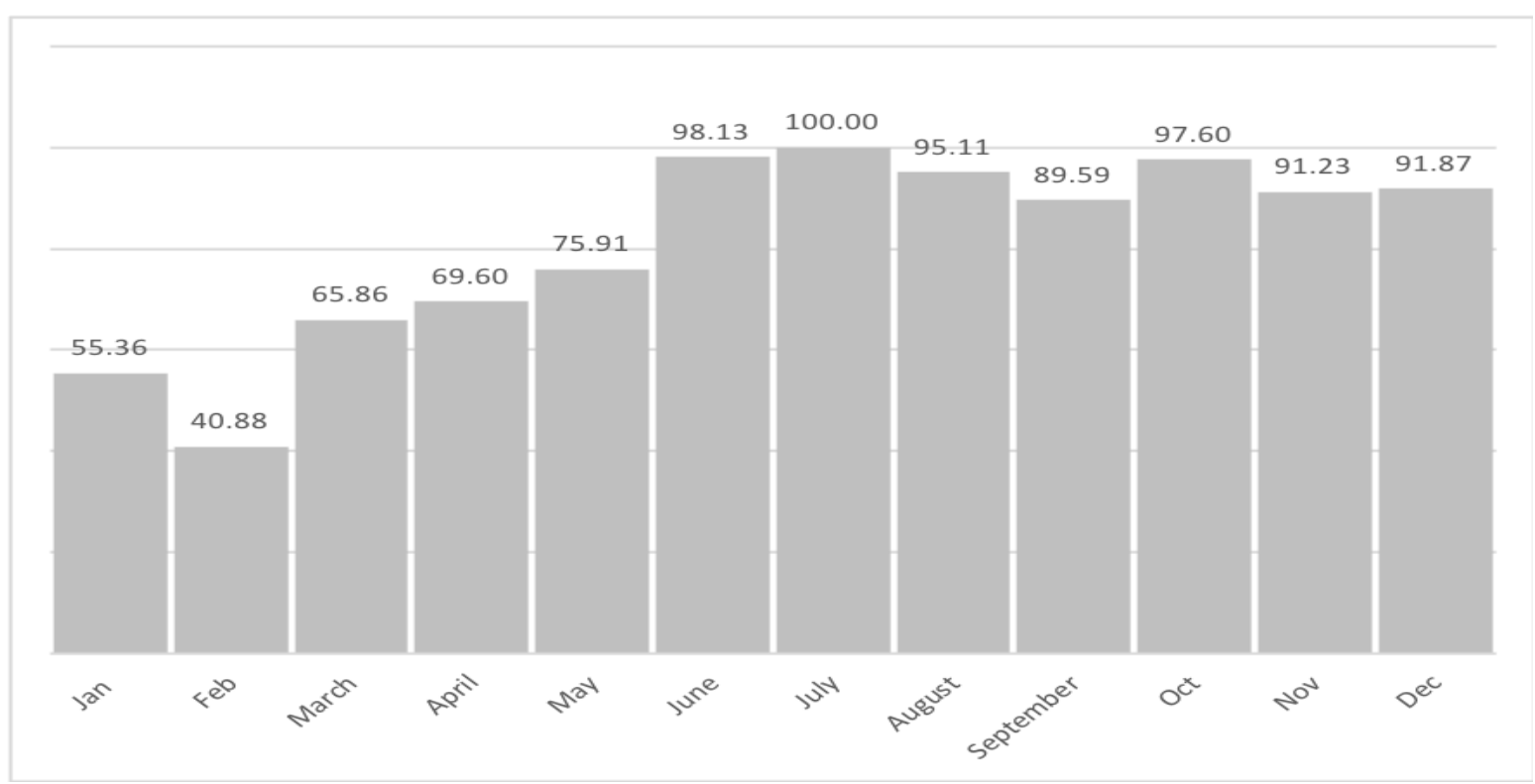


Seasonality in mason's work is no surprise, and in fact this rate of work is higher, and less seasonal than previous studies of the construction industry have implied. ${ }^{45}$ Figure 1 . shows average seasonal working patterns expressed as average total days per week (the number of men and the number of days they did) in each month over all five years. The numbers, based on total days worked, imply that in January there was only 55\% of the work intensity there was in July, and almost half the work intensity in Christmas quarter than there was in Midsomer.

St Paul's other records show that this pattern was not restricted to masons. Bricklayers, carpenters, labourers, plumbers and glaziers all submitted fewer bills for work done in Candlemas or the quarter of the year after Christmas, and while day bills are not a reliable guide to days worked, the call records for carpenters, which are full and reliable for parts of the 1690 s and 1700 s, show a consistently a smaller number of men and days in that quarter than others, as shown in table $5 .{ }^{46}$ At other sites, it is a similar story. Only men who had a regular position are usually found in January or first quarter records, and the highest number of casual hands and journeymen are usually found recorded as taken on in the weeks after Lady Day and the weeks after Michaelmas.

Table 5. Carpenters on day work, quarterly accounts, St Paul's, 1696-1700

\begin{tabular}{lll} 
& Men & Days \\
\hline Average Michaelmas & 28.4 & 57.6 \\
Average Christmas & 19.8 & 31 \\
Average Lady Day & 26.8 & 45.8 \\
Average Midsummer & 28.25 & 56.75 \\
Average total annual & & 191.15
\end{tabular}

This implies that the working year could not have been a full 52 weeks for all men, because there was not as much work available in January and February as there was in July. This seasonal restriction was a something akin to a structural bound to the demand for labour on large sites, although men could have found employment in alternative complementary work. For instance, masons working for Kempster could have spent the early months of the year in a

\footnotetext{
${ }^{45}$ Woodward, 1981 pp. 60-66, Table 3.2 p. 69. p.137-8; Campbell, 'The Finances of the Carpenter in England 1660-1710: A Case Study on the Implications of the Change from Craft to Designer-Based Construction', $p$. 324 , and p. 360 , in diabatto

46 These records are not in the same weekly format as the Kempster ones, rather a quarterly figure of number of men and number of days is given. LMA CLC/I/B/313/003/25473 no. 34-39
} 
workshop carving fireplaces and other stone monuments. ${ }^{47}$ Alternative work for unskilled or semi-skilled men could probably be found in transport and distribution which was centred on the river Thames and the nearby legal quays, but this was subject to high and lows of seasonal demand too. Over this first decade of the eighteenth century the average number of days in which anyone was working in Kempster's books was 289 days (48.2 weeks), which may be a good indication of the limit of available work in any one firm.

\section{IV}

What then of the weekly pattern of work? We know very little about hours of work and daily practice. In terms of the hours of work over a working week, reputedly, the bell at St Paul's rang at $6 \mathrm{am}, 1 \mathrm{pm}$, and $6 \mathrm{pm}$, implying up to an eleven-hour work day given breaks. ${ }^{48}$ The Middle Temple's records from June 1722 have a bill from Edward Stanton, mason, who was close to Kempster, which details half a day's work for a mason and three hours for a labourer costing a total of $2 \mathrm{~s} .{ }^{49}$ If masons were charged out at $3 \mathrm{~s}$. a day and labourers at $2 \mathrm{~s}$. a day (as was the rate in the other accompanying lines of the bill), then this would imply the amount for the labourers' three hours was just 6d., and it follows that three hours was a quarter of a day and 12 hours was a full day. Given the St Paul's bell evidence it seems a plausible working assumption that of those 12 hours up to 10 or 11 were worked. Therefore, if a man worked six days in a week he might have put in around 60-66 hours of hard physical labour, hauling stone and barrows around as well as fitting delicately wrought irons and precision cut ashlars. This is a higher number of hours than nineteenth century workers toiled, and frankly it would be hard to believe that anyone could be productive for that amount of time at that level of physical and mental output (although less strenuous work may of course have entailed longer

\footnotetext{
${ }^{47}$ Given a Mason's company search of September $26^{\text {th }} 1694$ found in total 326 working masons in London, of which 120 were working at the Cathedral for various contactors, 114 at other sites, and 92 others in small numbers of 1-8 men in workshops and at other locations it is not plausible that there would have been full employment for all men in January and February when there were a much smaller number on site at the Cathedral.

${ }^{48}$ This is a relatively short working day compared to many references of $12-17$ hours at shipyards, (although the standard day was twelve hours and longer period only worked at times of high demand) Haas, 'The introduction of task work', pp.65-66; Chase Early Trade Unionism: Fraternity, Skill and the Politics of Labour, p.43.

${ }^{49}$ In folder ACCVOUBI MT.2/TUT, Middle Temple Archives.
} 
hours as evidenced by domestic service). Indeed, in the past it was assumed that most of the population lacked the nutrition to do so. ${ }^{50}$

Half days were common, both in bills and accounts, and they are common in Kempster's records, but there does not seem to have been a capacity or allowance for 'overtime', as there was in the Royal Naval Dockyards where when demand was high days, tides and nights were worked implying a working day of well over 12 hours. ${ }^{51}$ For those who worked by task, the likelihood is that they followed the same work day, as most task work was carried out on the same sites, although we have no way or evaluating or evidencing this. For the vast majority, we should view a six day, 66-hour week as the upper bound on work hours in construction. However, the occurrence of half days demonstrates it is not the case that everyone worked a full week, even if they were on site all days. This lack of full adherence to a full, formal working week chimes with earlier literature on early modern working patterns based on the days on which couples were wed. ${ }^{52}$ The number of full days a man worked when he was on site in a week can be used as an indication of 'industriousness'. The weekly figure, never available from any other source, can reveal if casual leisure time, or some sort of SaintMondays were keeping labour inputs low as the literature about older working patterns and increasing eighteenth-century industriousness story has always implied. ${ }^{53}$ Unfortunately we cannot tell whether days not worked in any week were because Kempster was economizing on wages by telling some men not to come in on some days, or whether men were choosing leisure.

Table 6 shows the average number of days worked when on site, calculated as a mean average of the number of days worked per week, using only the weeks where work was recorded, and excluding Christmas and the Easter weeks.

\footnotetext{
${ }^{50}$ Freudenberger and Cummins 'Health and Nutrition', also note Boulton's observation of the absence of a regular and intensive working week in the late sixteenth and early seventeenth centuries in Boulton, 'Economy of time? Wedding days and the working week in the past',

${ }^{51}$ Rewards 'for extra worke' appear in the London Bridge and Office of King's Work records for the late seventeenth century. Such payments were a small percentage of a weekly wage, (a shilling or two for a week's work) and have only been observed paid to regular workers. The nature of record keeping means that these payments are not present in later records from the latter part of the eighteenth century.

52 Boulton 'Economy of Time?' p.33; Reid 'Saint Mondays revisited' p. 143

${ }^{53}$ It should be noted that most of the evidence of St Mondays comes from a period much later than the one studied here, and from outside London, Reid, 'The decline of St Monday'; also see the excellent list and exposition in Kirby 'Attendance and work effort'. There is no published evidence of Saint Monday being customary or practiced in London in the early eighteenth century.
} 
Table 6. Average number of days worked by craftsmen in a week when on site

\begin{tabular}{llllll} 
& $1700-01$ & $1701-2$ & $1706-7$ & $1707-8$ & $1708-9$ \\
\hline $\begin{array}{l}\text { All men } \\
\text { <18d. }\end{array}$ & 5.36 & 5.27 & 5.21 & 5.20 & 5.12 \\
$18 d$. & 5.37 & 5.50 & 5.33 & 5.30 & 5.18 \\
19-27d. & 5.44 & 5.37 & 5.24 & 5.22 & 5.07 \\
28d. & 4.62 & 4.23 & 5.34 & 5.01 & 5.04 \\
29-30d. & 5.48 & 5.23 & 4.96 & 5.23 & 5.47 \\
32-34d. & 5.25 & & 4.73 & 5.75 & 5.50 \\
36-40d. & 5.84 & 5.29 & 5.58 & 5.53 & 5.71
\end{tabular}

Notes: Christmas and Easter weeks are excluded. Average of all observations = 5.2.

The number, mostly well above 5, and an overall average of 5.2, implies that there were not a lot of regular leisure days, but it also clearly shows that a full six day working week was not sustainable for most workers, although mostly men worked hard when they were employed. As more than five days were being worked on one site it would be unlikely that work was being taken up elsewhere. Since the books don't show many regular days where everyone was off it seems men chose leisure or a half day off on an individual basis rather than follow a prescribed pattern of holidays, or they used a half day or day per week to search for new work. ${ }^{54}$ As the figures are higher in the latter two years, when there were higher numbers of men on site also it seems plausible that the industriousness was to some extent determined by Kempster's demand for skilled labour. The days worked per week figure firmly points to the fact that the working week on this site was bounded below a full 6 days.

Combined with the annual weeks worked figures the implication is that if the working year was bounded by the seasonal low demand for workers in January and February, and the working week by the ability of men to sustain or supply labour, then the number of days most men, or the 'average man' could have worked, assuming constant employment would have been at maximum, 48.2 weeks of 5.2 days, or just 250.6 days, but this figure could only be an average working year if all men would have had the opportunity to work all 48 weeks. However, as the following section shows the evidence firmly indicates some did not.

$\mathbf{V}$

\footnotetext{
54 The best discussion of leisure preference in this period is Hatcher 'Labour, Leisure and Economic Thought' pp.64-115, for possible sickness rates - too variable and too small to be applied to such a data set as this see Riley 'Sickness in an early modern workplace'
} 
As table 7 shows the average number of weeks actually worked by all men in Kempster's over the five years team was about half of the maximum possible, and in only one year did as many as half the team work over 40 weeks for Kempster. Whilst the number of days worked in a week might be a useful indicator of leisure preference of industriousness, the number of weeks worked, beyond seasonal factors discussed above, is more likely to have been influenced by employer's demand for labour than worker's preferences. There are two main reasons why contractors demand for men would vary. Firstly, as discussed above, stage dependent skill requirements. Secondly, to handle increased work intensity. When there were problems encountered, a new deadline or increased contract scope extra men would be needed, and unless they made themselves indispensable to the team they would go again when the demand slacked off, and those with stronger ties would remain. ${ }^{55}$ Since the work Kempster doing was of a specialist nature this may have been the case to a greater degree than on a site where there were homogenous skill requirements, although the period through which these day books record work were the busiest at St Paul's when labourer and carpenter days worked were at their highest. ${ }^{56}$

Table 7. Average number of weeks worked for all men in all years

\begin{tabular}{llllll} 
Weeks worked & $1700-1$ & $1701-2$ & $1706-7$ & $1707-8$ & $1708-9$ \\
\hline $\begin{array}{l}\text { All men } \\
\text { <18d. }\end{array}$ & 27.68 & 31.05 & 22.62 & 26.88 & 21.45 \\
18d. & 33.70 & 26.00 & 20.24 & 25.70 & 16.09 \\
19-27d. & 35.29 & 28.75 & 30.53 & 31.00 & 27.08 \\
28d. & 7.33 & 20.50 & 21.93 & 24.53 & 21.25 \\
29-30d. & 24.00 & 45.20 & 22.26 & 30.53 & 34.40 \\
32-34d. & 29.00 & & 11.10 & 2.00 & 5.00 \\
36-40d. & 8.50 & 47.00 & 47.00 & 48.50 & 30.50 \\
Over 40 weeks & $39.29 \%$ & $52.63 \%$ & $22.55 \%$ & $38.46 \%$ & $27.27 \%$
\end{tabular}

Kempster's books imply that skilled and semi-skilled men were working only a small part of the year with Kempster, and then, although work was still available for their level of skill, they left the team and moved elsewhere. Only a small number of men sustained a long relationship with him at this site (only 10 of those present in October 1700 were still

\footnotetext{
${ }^{55}$ Given the figures' noticeable difference from the established economic history literature its worthwhile entertaining the idea that Kempster was just bad at managing his team or paying rates too low to keep good men. Since the results are the geometric staircase at St Paul's this is a hard argument to sustain, particularly since Kempster became an office holder as head mason at St Paul's in the years after this.

${ }^{56}$ As indicated by the day bills, which are only indicative as some work was carried out by task or other contract.
} 
employed at all in 1708-9), the rest worked for Kempster elsewhere; worked for other contractors at St Paul's or had other work lined up; or they faced the search for new work, we have no way of knowing.

Churn among the team at St Paul's might indicate poor matching but it also might be an indication of a busy market for skill, where specialists had many options for employment in the wider environment and Kempster had choice of a wide variety of skill to deploy. Assuming that those that stayed with Kempster for the long term were a good match for his skill requirements and team composition, those that departed presumably did not match as well, but presumably found work and matched elsewhere. Although having so many men come and go may create uncertainty, inefficiencies, and extra monitoring, it is always common in construction.

However, no matter what their circumstances, the total number of weeks work that any man achieved in any year will have been affected by two things: frictional costs - search and matching - and the labour demand of other contractors which was affected by the seasonality that limited work availability in the Christmas or Candlemas quarter. In a buoyant market with high labour demand, as London probably was in this period, the costs of finding work would have been small for workers, so even if they did not match immediately they will have found work after a short time. However, even if there was lots of work to be taken up, and matching was easy it will have been harder to find work in Candlemas than Midsummer or Michaelmas, and so if searching at this time of year their search will have been longer, and they will have worked fewer days. When the demand for building work slumped, as we know it did after 1725, and again after 1735 there will have been a much tougher and longer search for work in all quarters. ${ }^{57}$

Although it is likely that men quickly took up work elsewhere in booming market we can't presume that men always took up work at the same or better rate elsewhere because within Kempster's own team there are examples of men having taken a lower rate to remain, and there is no identifiable trend where by new men were hired at higher rates than old. Through October to December 1700 Thomas Bayley and Thomas Lutter earned 26d. per day. When they started work again in early 1701 they were paid $24 \mathrm{~d}$. per day and remained on that rate

\footnotetext{
${ }^{57}$ Sheppard, et al. 'The Middlesex and Yorkshire deeds registries and the study of building fluctuations', pp.176217; Also see Barras, Building Cycles, pp. 6-8, 154-178, and 180
} 
throughout the whole of 1701 and 1702. They earned 26d. per day each again from $1706 .{ }^{58}$ This of course also implies that skilled men may have taken up unskilled work if specialist work at their rates was not available, maintaining their number of days worked but at a lower income. $^{59}$

It would only have been possible for men who left Kempster's team to have worked over 250 days a year if, on leaving the team after 20 - 30 weeks they found work within 3 weeks and were permanently employed by one contractor for the rest of the year, or seamlessly moved from one job to the next with no loss of weeks, or if they made up any lost days by increasing their weekly working intensity and working the full six days per week. If they left the team at the end of December and did not find work again until the end of February but worked without break for the rest of the year they would have worked approximately 220 days, but any subsequent breaks would have reduced their total working days further.

\section{VI}

Kempster's wage records show not only much lower number of days worked in that team that the literature has led us to expect, but also a very high variation, or wide distribution in the number of days worked by individuals. The finding that only a small number of workers were employed full time, year-round by employers is nothing new in early modern labour studies. ${ }^{60}$ Is there a way to distinguish the men who tended to work more weeks in the year from those who did not? The most significant factor that influenced the number of days they worked for Kemspter was tenure or the length of time they had a relationship with Kempster. There is a clear relationship between the duration of time that a man had worked for Kempster, and the number of days a man worked in any year as shown in figure $2 .{ }^{61}$

\section{Figure 2. Plot of average no. of days worked by day rates (all years)}

\footnotetext{
${ }^{58}$ And see the description of William Stonhouse's day rates in Section 1, above.

${ }^{59}$ Of course, if skilled men took unskilled work this will have displaced unskilled workers and affected their search and number of days worked.

${ }^{60}$ See Burnette, 'The seasonality of agricultural employment', Muldrew 'Wages and the Problem of Monetary Scarcity in Early Modern England,' Hassell Smith, 'Labourers in Late Sixteenth-Century England' and Woodward op. cit. chapter 4 and table 4.2

${ }^{61}$ Since these records do not show the working days in 1703- 4 the length of tenure cannot be accurate.
} 


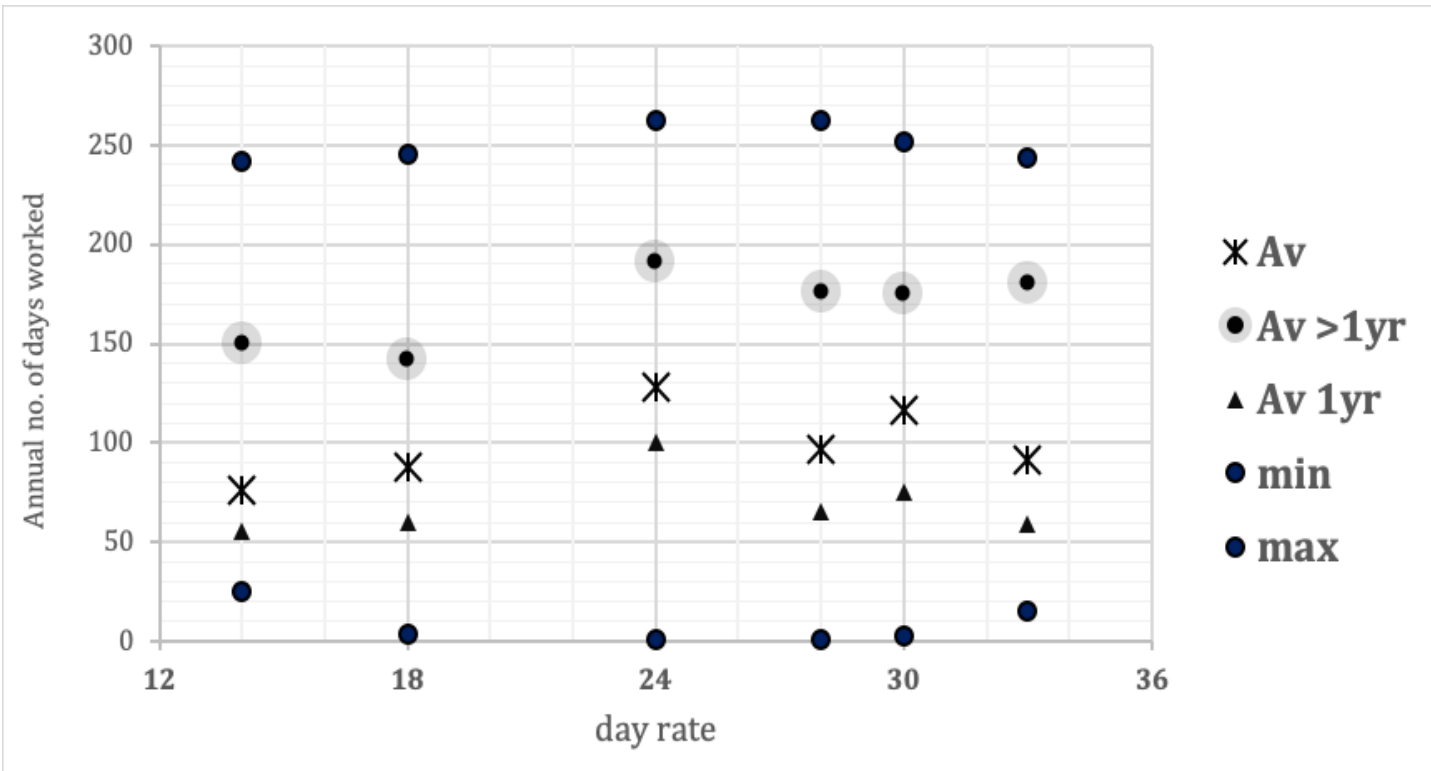

There is a possible indication of an inverse relationship between the number of days worked per week, and the rate of pay (in table 6) where the average number per week for men at $18 \mathrm{~d}$. is over 5.2, and the average for men at $28 \mathrm{~d}$. and above is just under 5, however, the relationship will also be affected by a small numbers problem at the higher end of the wage scale. It does seem that men who had a longer relationship with Kempster got more work, or more regular work patterns although this could also be a function of seniority. Without longer run records for a bigger team this relationship between tenure and regularity, or steady work cannot be confirmed.

For comparison table 8 shows the number of days worked over a 14-month period by plasterers working on the Dome in 1707-8. ${ }^{62}$ This was a dedicated team, who worked on the Cathedral on a specific fixed task, billed in one unit - and where, because quality was a key consideration Wren wanted it performed and contracted by the day. The team were under time pressure (as plasterers always are). The average is a little higher than the masons, and the team more stable, but the average for a tight knit team still falls far short of the 250 days assumed by other authors. The average of all the craftsmen who worked over 200 days was only 228, and all the others had an average of just 108 days worked in the year. Again, obviously, the men worked elsewhere, but the very fact that work was not at full intensity for all throughout, and that team members would have been looking for work and bargaining for

\footnotetext{
${ }^{62}$ LMA CLC/313/B/1/MS25473 NO 41 p.51 Christopher Wilkins bill. Wilkins received £50, over and above the day rates for the contract. The data is only given in aggregate.
} 
it throughout the year reiterates the point that an assumption of a sustainable average of 250 days' work is too high.

Table 8. Plasterers at St Paul's, 1 Sept. 1707-31 Oct. 1708

\begin{tabular}{lll} 
& \# days in 14 months & Implied 12-month \# \\
\hline Thos Jenet & 58.5 & 50.14 \\
Step Blackely & 261 & 223.71 \\
Ch Doogod & 193 & 165.43 \\
Ino Thoimpson & 136 & 116.57 \\
M Cole & 116.5 & 99.86 \\
Th. Morse & 283 & 242.57 \\
M Stafacre & 283 & 242.57 \\
W. Aflet & 271.5 & 232.71 \\
Ch. Ginks & 259 & 222.00 \\
Robert Crivens & 241 & 206.57 \\
Average & & 180.21 \\
Median & & 214.29
\end{tabular}

Source: LMA, CLC/313/I/B MS25473, no. 41.

Without being able to estimate the costs of skill matching or job search for workers in this market we cannot accurately construct an average income. There are, at present, few facts or models with which to construct a likely estimate, other than try to estimate the number of weeks it would have taken to find stable, or regular work. Since St Paul's was active as a site for so long (four decades) it may have distorted these factors over the very long run. Other sites were usually active for much shorter periods implying greater search costs. Greenwich Hospital was completed within a decade 1696-1706, the Fleet ditch was done under three years (1671-4), most City Churches were completed within five years even if further works on spires and fitting out was recommenced after a break. Most residential construction took less than a year. ${ }^{63}$ On maintenance projects such as London Bridge most men were employed by the tide, or, as here, did not work every week. ${ }^{64}$ Frictions of search and matching will have been greater on other projects, unless consolidation in the industry and firm size led to better team composition. There is no evidence that this was the case until

\footnotetext{
${ }^{63}$ Although speculators and subcontractors may have kept teams working site to site McKellar, Birth of Modern London, Chap. 2, 6.

${ }^{64}$ See LMA Bridge House Estates CLA/007/FIN/004
} 
the very end of the eighteenth century. The organizational basis of the industry was unchanged until the $1820 \mathrm{~s} .{ }^{65}$ High job churn in construction is still typical today. ${ }^{66}$

Eighteenth century urban building craftsmen and labourers' working year was bounded by structural demand factors of seasonality and the building process, and the frictional costs of finding regular employment, and bounds on their own ability to work at physical or full intensity throughout a six-day week. The evidence from a unique single firm source on a large and well-resourced site indicates that on average men might only have worked 5.2 days per week in the long run, and if they did not have a regular employment relationship they could have worked less than thirteen weeks in the year for any one employer. Even employees who had worked with an employer in two years previously might still only have had 35 weeks work with him on average, equivalent to 182 days' work per year. If they worked more than this it will have been for other employers with the associated costs or frictions of search and bargaining.

\section{VII}

Building construction workers were never more than about 8-10 per cent of the working population, and the data presented here comes from just one firm, in one decade of the early eighteenth century, so do these findings have any bearing on theories about industriousness and industrialization? In short, for urban workers, yes, because builder's day wages are the source of the urban wage data on which research on such matters relies.

There are two main implications of the examination of the way the working week and year worked for building craftsmen. The first is the fairly straightforward finding that calculating early modern income, or the 'real wage' on an average of 250 days of building craftsmen's pay distorts our understanding of the levels of income, and the means and amount of employment. Because at present we use builders' wages as a proxy for the average of all

\footnotetext{
${ }^{65}$ Clark, Building capitalism, pp. 34-35, Cooney 'Victorian Master Builders', Knoop and Jones, The London Mason in the Seventeenth Century.

${ }^{66}$ For modern differences in Construction industry labour market frictions see Davis, Faberman, and Haltiwanger, 'Recruiting Intensity during and after the Great Recession', National and Industry Evidence, pp.584-588. For the length of other projects see Wren Society, Volume X pp.52-54. TNA ADM 67/2.
} 
wages, it overstates average income. If the amount builders earned per day was lower, and the number of days they worked were fewer then annual incomes would have been about $40 \%$ lower than the current predicted $£ 31.00$ - $£ 37.00$ for craftsmen, and $£ 20.00$ - $£ 25.00$ for labourers (table 9). What we have thought of as a labourer's income was actually a craftsman's. On this basis a 'respectability' basket could only have been attained by craftsmen, not labourers. ${ }^{67}$ Tables $10 \mathrm{a}$. and b. illustrate this point in welfare ratios based on Allen's consumption basket. Londoners working in skilled construction still look to have had a good standard of living, but there is research to be done on the formation of their income and their relative comfort compared to workers in other cities in Europe. ${ }^{68}$ One should caution that household composition, substitution and prices may also have been different to what we currently think. A household with one adult male supporting a wife and children was quite rare in London at this time. ${ }^{69}$

Table 9. Projected annual income for construction workers at given day rates and number of days worked

\begin{tabular}{lllll} 
Day rate in d. & 150 days & 180 days & 200 days & 220 days \\
\hline 12 & $£ 7.50$ & $£ 9.00$ & $£ 10.00$ & $£ 11.00$ \\
17 & $£ 10.63$ & $£ 12.75$ & $£ 14.17$ & $£ 15.58$ \\
24 & $£ 15.00$ & $£ 18.00$ & $£ 20.00$ & $£ 22.00$ \\
26 & $£ 16.25$ & $£ 19.50$ & $£ 21.67$ & $£ 23.83$ \\
28 & $£ 17.50$ & $£ 21.00$ & $£ 23.33$ & $£ 25.67$ \\
30 & $£ 18.75$ & $£ 22.50$ & $£ 25.00$ & $£ 27.50$
\end{tabular}

Table 10a. Craftsmen's revised welfare ratios (WR) for London, with nominal wage deflated by $20 \%$

\begin{tabular}{llll} 
& WR Allen 250 days & WR -20\% 250 days & WR -20\% 200 days \\
\hline $1650-99$ & 1.96 & 1.57 & 1.26 \\
$1700-49$ & 2.1 & 1.68 & 1.34 \\
$1750-99$ & 2.09 & 1.67 & 1.34
\end{tabular}

Table 10b. Labourers' revised welfare ratios (WR) for London, with nominal wage deflated by $30 \%$

\begin{tabular}{llll} 
& WR 250 days & WR -30\% 250 days & WR -30\% 200 days \\
\hline $1650-99$ & 1.30 & 0.92 & 0.73 \\
$1700-49$ & 1.50 & 1.05 & 0.84 \\
$1750-99$ & 1.35 & 0.95 & 0.75
\end{tabular}

\footnotetext{
${ }^{67}$ Allen 'The British Industrial Revolution' pp.39-44; Prices and wages in SE England',

${ }^{68}$ For comments on comparison see Stephenson 'Mistaken wages' pp.10-13

${ }^{69}$ Humphries 'The Lure of Aggregates'; Merry and Baker, 'For the house her self and one servant', pp.205-232
} 
Note: These calculations are based on the nominal wages and welfare ratios for London at Robert Allen's pages at nuffield.ox.ac.uk were arrived at by reducing the London nominal silver wage by $20 \%$ and $30 \%$. The data are denominated in silver in this series.

The second implication relates to how useful builders work, and working records is in estimating increased 'industriousness' or working hours, and by implication economic growth, whether that was as Humphries and Weisdorf assert - in the early seventeenth century, or as the previous literature has assumed, the eighteenth. ${ }^{70} \mathrm{St}$ Paul's represents a large site, with consistent and high demand for labour in the first decade of the eighteenth century, yet with both seasonal and weekly bounds to industriousness it is unlikely that many men on that site could have worked 250 days. Furthermore, the mechanism by which they could have worked more, either then or in other decades is unclear. Without the decline of a widely recognised custom such as Saint Monday to account for the extra days, and given the seasonal and sequential labour demand bounds only if there was some sort of structural change or a sustained increase in building demand could workers have achieved the higher number of days. It may well be that a process of consolidation in the industry increased firm size and allowed more retained workers, but at present this is thought to not have happened until the 1820 s.

Although building has some unique seasonal and frictional constraints, other London workers will also have experienced seasonality, idiosyncratic weekly patterns and the search for work..$^{71}$ London was increasingly a service economy in the long eighteenth century and building and construction, led by Wren and his associates was at the vanguard of much of the organisational and technical innovation. ${ }^{72}$ There is no evidence of holy or Saint's days in the accounts of tradesmen and women who transacted with institutions with large building sites, but the seasonal patterns would have been similar to construction in many ways. Most service workers were retained or paid by commission which would have fluctuated with seasonal supply and demand. Significant groups affected by such would have included those who worked on the river in transportation and distribution, retained service workers such as porters, servants and domestic staff in large organizational institutions such as the Temples and the Hospitals, and those privately retained by individuals. River workers' working year

\footnotetext{
${ }^{70}$ Note that the Humphries \& Weisdorf approach negates part of the Voth thesis that hours worked extended through the eighteenth century, as in their analysis, as they say, hours cannot be observed.

${ }^{71}$ The idea that time value only became part of the wage bargain after industrialisation is a long standing one in economic history, see Hobsbawm 'Custom, Wages and Workload' and Schwarz 'Custom Wages and Workload' ${ }^{72}$ Addis, 3000 years of Building Design, pp. 156
} 
were as bounded as construction ones, with weather and supply of transported goods constraining demand at Candlemas. Manufacturing was mostly piecework. ${ }^{73}$ Slower demand for goods impacted demand for the service workers who sold, packaged, counted, or processed them. If, as recent scholarship has asserted on a number of counts, early modern economic growth and industriousness began in the seventeenth century, at least 150 years before factory discipline, ${ }^{74}$ there is much new research to be done on how employers and workers co-ordinated an associated increasing volume of work per worker. This is all the more an important research agenda given that growth is increasingly associated with the tertiary sector where factory discipline cannot have been a factor, rather than the manufacturing sector. ${ }^{75}$

\footnotetext{
${ }^{73}$ Shaw Taylor et al, 'Male Occupational Change and Economic Growth' show that the typical London household did not contain a wife, and husband and children but a mix of young and older adults, earners, servers and lodgers.

${ }^{74}$ Broadberry et al British Economic Growth; Humphries \& Weisdorf 'Unreal wages'; Crafts and Mills, 'Six centuries of Economic Growth: A time series perspective'

${ }^{75}$ Broadberry et al British Economic Growth pp. 163-175, Crafts and Mills, 'Six centuries of Economic Growth: A time series perspective'pp.141,156.
} 